\title{
Fluidity and persistance of cultural narratives: Heritage tourism and cultural narratives for insiders and outsiders in Western Mongolia
}

\author{
Holly Barcus
}

\begin{abstract}
Framed within contemporary debates about the implications of cultural heritage tourism for rural ethnic minority populations, this paper explores the case study of cultural heritage tourism in Bayan Ulgii Mongolia, juxtaposing arguments about place and identity with those of economic benefits. Preliminary results suggest that growing attention paid to the Kazakhs as aminority ethnic cultural group in Mongolia, and narratives of their lifeway persistence, increase international acknowledgement that mayfoster greater tourism. However, one of the key outcomes of the production of this heritage landscape is the consumption of ethnic cultural identity narratives by ethnic Kazakh out-migrants who desire to reinscribe "traditional cultural lifeways" in their children's identities. This thus serves to promote a shared sense of identity amongst a rapidly dispersing population but also challenges the notion of production and consumption as competing, rather than complimentary processes, in emerging rural tourism locations of the Global South.
\end{abstract}

Keywords - cultural tourism, Ulgii, Olgii, identity, narratives, diaspora

\section{INTRODUCTION \& BACKGROUND}

$\mathrm{T}$ oday, cultural tourism seems to be omnipresent, and in the eyes of many it also seems to have become omnipotent. It is the holy grail of quality tourism that cares for the culture it consumes while culturing the consumer. Cultural tourism has therefore been embraced globally by local, national, and transnational bodies. UNESCO promotes cultural tourism as a means of preserving world heritage, the European

Received: 10-11-2017, Accepted: 03-12-2017; Published: 30-6-2018

Holly Barcus, Department of Geography, Macalester College, Saint Paul Minnesota

Email: barcus@macalester.edu
Commission supports cultural tourism as a major industry, and the newly emerging nation-states of Africa and Central Europe see it as a support for national identity. In many parts of the world it has become a vital means of economic support for traditional activities and local creativity" ([20], p.1, emphasis added).

As Richards [20] so clearly describes, cultural tourism globally has grown from a micro, niche industry largely dominated by affluent and highly educated tourists to a dimension of the tourism industry which eclipses ecotourism and other traditional forms of mass tourism ([12], p.1). Today individuals easily travel to places that were once accessible to only the most intrepid travelers. Experiencing different places and peoples is thus increasingly democratized, allowing greater opportunities for travelers to experience remote, previously inaccessible regions of the world. For the residents of these regions, such access has provided both opportunities to generate income and share culture as well as challenges to maintaining "authentic" culture and place identities. Johnston [8] highlights a few of the issues related specifically to indigenous peoples and tourism including questions of land rights, self-determination and sacred sites while Franquesa and Morell ([6], p.171) further note the importance of recognizing power relations within communities that might influence which elements of heritage and culture are promoted or potentially made more vulnerable. Places such as Mongolia, with its unspoiled grasslands and indigenous herding cultures combined with images of flowing grasslands dotted with picturesque felt tents has become increasingly attractive to adventure tourists as well as cultural heritage enthusiasts. Indeed, the land of Chinggis Khan attracted over 400,000 foreign tourists annually from 2010-2013 ([16], p.161). One need venture only a short 
distance beyond the capital city of Ulaanbaatar to experience a wide range of Mongolian traditions, foods, and lifeways.

For an increasing number of travelers, however, Ulaanbaatar is merely the first stop in Mongolia. The periphery of Mongolia, whether the northern edges bordering Russia's Siberia, or the southern periphery with the legendary Gobi desert, offer a more selective, albeit rugged, experience. For cultural enthusiasts, there are several tiny ethnic minority populations with well-preserved traditions still practicing nomadic lifeways in remote regions of the country. These include, among others, the Dukha(Tsaatan), or reindeer herders of the far northand the Kazakhs of the far western provinces of Mongolia. Located in the hinterlands amongst stunning scenery, these cultural landscapes attract tourists seeking "authentic" and perceived "exotic" cultural experiences in these remote and less accessible places. Cultural groups leverage their ethnic identities to produce tourist experiences as a means of diversifying household economies. One outcome however is the perpetuation of a cultural narrative that promotes the uniqueness of particular ethnic identities and is consumed by both outsider tourists as well as former co-ethnic residents who live away from the cultural hearth.

This paper questions the role of tourism in sustaining cultural narratives for remote rural ethnic minority populations in Mongolia. Based on several periods of fieldwork in western Mongolia and Ulaanbaatar, I argue that cultural heritage tourism in Bayan Ulgii Mongolia has evolved to serve two audiences and that for these two audiences there are two distinct narratives of culture and consumption. This dual narrative is constructed and consumed by outsider tourists on the one hand and, on the other hand, is consumed by insider co-ethnics, largely comprised of members of the Kazakh diaspora now living away from the home region.

Culture and tourism

There exist a myriad of definitions of "cultural tourism". McKercher and du Cros ([12], p.1-9) highlight the nature of the phrase, arguing that "cultural" can refer to the multitude of activities and sites that comprise the heritage of a particular group of people while "tourism" is inherently about the tourist and the nature of what is being consumed. Thus one of the focal points of tourism infrastructure is the tourist. McKercher and du
Cros ([12], p.139) highlight a typology of five types of cultural tourists, based on the "importance of cultural tourism in the overall decision to visit a destination and depth of experience". Their typology includes the purposeful cultural tourist, sightseeing cultural tourist, serendipitous cultural tourist, casual cultural tourist and the incidental cultural tourist ([12], p.144). Each type engages with cultural tourism activities at varying levels of intentionality.

Heritage tourism, as a subset of cultural tourism, is often promoted as having several key advantages over other, primarily mass, forms of tourism for local areas. These advantages include heritage preservation, expansion of household economies in remote regions, and the creation of opportunities for development such as might be expressed through local or individual entrepreneurism or more broadly as a means of poverty reduction and economic diversification (see for example [23; 22]).

From the perspective of heritage preservation, artifacts and lifeways are seen to be preserved or recognized as valuable. As McIntosh et al. ([11], p.39) argue "For indigenous communities, tourism is seen as a step towards building new meanings for traditional practices and reaffirming values, and ultimately as a means of economic empowerment and cultural independence". Household economies may be further expanded through the production of "artifacts" which can be sold, or through food production and sales. One example in Western Mongolia is the Altai Craft cooperative where traditional textiles were produced by local Kazakh women and sold to tourists and other visitors. Women producing the textiles are paid for their work in the cooperative. This provides both additional household income and helps sustain the local craft production knowledge. Homestays also have the potential of highlighting traditional foods and herding practices while simultaneously increasing the diversity and depth of a household budget.

Lastly, rural development and tourism are increasingly seen as complimentary investments. Thus, these activities and opportunities for smallscale entrepreneurship are perceived as a valuable development option for remote communities seeking external sources of income and as a development tool for reducing poverty [24]. Accompanying the advantages purportedly tied to 
heritage tourism, however, are equally compelling disadvantages or challenges that emerge from heritage tourism in remote communities (see for example [8, 12, 24]). For example, the democratization of travel has shifted cultural tourism sites to mass tourism sites. This is a significant disadvantage to small-scale tourism destinations. Inexpensive travel and the proliferation of information about remote communities and cultural groups, has expanded small potential tourist markets. This challenges the "small scale, non-invasive" preservation narrative of heritage and cultural tourism. The shift to larger scale tourism also challenges the idea of "cultural exchanges" as there is no longer the intimate cultural exchange between a few tourists and local people but rather the interaction is scaled-up to accommodate significantly larger groups. Cultural preservation then begins to take on more of a performance aspect.

A second critique focuses on the "commodification of culture". This critique rests in the question of who is in control of the tourism development process. Franquesa and Morel [6] argue that commodification is a process largely controlled by those in power and that land and resource controlled by an elite population can increase the price of resource use thereby further disadvantaging or dividing local resources. The question of who defines heritage is also key. This influences, for example, which artifacts, locations or landscapes become "heritage" and which ones do not [6]. Questions thus of power-relations within a community may over or under-emphasize particular cultural resources.

Culture, heritage and identity, and their representations can be highly fluid and contested ideas. While often at the core of cultural tourism, places and the meanings ascribed to them may reflect particular, and likely not universally held, perspectives on the importance of or stories behind a site or artifact. The narrative or story of a particular place inclusive of people and environment is one that engages different histories and experiences and perceptions of those histories and experiences. How these varied histories are portrayed for an external, tourist audience, rests on local dynamics of power and voice. Those with significant social capital are more likely to influence the narrative of place than those will less social agency. Narratives of culture and history of a place might utilize memories as a means of interpreting and experiencing place. Keitumetse et al. ([9], p.158) write that "Intangible heritage components have a potential to enable a profound implementation of ecotourism, particularly in landscapes where tourism already thrives but where intangible heritage is or has been overlooked". The sharing of these individual histories and perspectives on heritage and culture underscore notions of "authenticity" but also provide a more diverse sense of a place history and identities associated with it. Thus the commodification process may simplify the narrative of identity associated with a place, highlighting those aspects most highly valued by individuals or groups with the greatest local influence, while potentially overlooking other narratives or perspectives. In another example, Worden [25], writing about the Malay people, describes the process by which Balinese music and art became known globally through the selective telling of cultural history. Such selective telling shapes cultural narratives for both insiders and outsiders and underscores the importance of recognizing different voices in heritage tourism development.

Memory and identity are also important aspects of tourism for those seeking to reconnect with their own heritage or ancestry. One dimension of tourism to Ireland or to Israel has long been associated with the diaspora of these places, commodifying aspects of identity and place for individuals interested in exploring their own heritage $([1,10,7])$. Such diaspora tourism has the potential to increase development in Global South countries where tourism infrastructure may not be as developed and which, through the diaspora, more locally-owned businesses are likely to be utilized during the stay [14].

"Tourists from the diaspora, however, are more likely than most international tourists to have or make connections with the local economy; to stay in locally owned, smaller accommodations (or with relatives); to eat at local restaurants; and so forth. While they may not spend as much money as foreign tourists, on average, diaspora tourists' expenditures are more likely to go directly into the hands of local businesses. Thus they generally have a different and, in some respects, more positive development impact" ([14], p.4).

Thus some places attract tourism from a diaspora which is seeking to inscribe in personal histories a sense of belonging to a place or 
peoples. Such diaspora tourism, as a form of cultural tourism, is emerging in the Global South and Bayan Ulgii, Mongolia is a good example of how such niche tourism may be emerging.

In summary, for remote rural communities, cultural and heritage tourism has the potential to increase development and diversify household economies but tourism development inevitably results in a degree of commodification of a particular place and its' residents heritage or culture. While culturally distinctive places will attract a range of cultural or heritage tourists, the emergence of a flow of tourists from the diaspora may create a different market and potentially influence the narrative of livelihoods portrayed at a particular location.

\section{MONGOLIAN KAZAKHS AND BAYAN ULGII AS A TOURIST DESTINATION}

Kazakhs are the largest minority ethnic population in Mongolia, comprising about 3.86\% [15] of the total population and are culturally distinct from the dominant ethnic Khalkha Mongol population. They practice a different religion (Islam as opposed to Bhudhism), speak a different language (Kazakh as opposed to Mongolian) and, while maintaining similar seminomadic lifeways, the material artifacts and foodways are distinctive across the two populations. The cultural hearth of the Kazakh population in Mongolia largely centers on the province (Aimag) of Bayan Ulgii. Although there are Kazakh populations spread across the country, the largest concentrations are found in Bayan Ulgii, and Hovd Aimags, in western Mongolia as well as the capital city of Ulaanbaatar. Tourism in this western region is not highly centralized, rather there are key tour operators, some of whom have been operating since the early 2000 s and independent guides as well as many other smaller household businesses that support general tourism activities. Bayan Ulgii is frequently highlighted by Ulaanbaatar-based tour companies to tourists seeking a more "authentic" experience with ethnic minority groups. The Kazakhs, and the Dukha, or reindeer herders of northern Mongolia, are the two populations most visited and celebrated as ethnic minority populations. Indeed, the Kazakhs have recently garnered international attention through the release of the 2016 motion picture film The Eagle Huntress [21]. The October Eagle Hunting Festival in Bayan Ulgii attracts a growing number of visitors each year as a single event although the months of July and August garner a fair number of tourists generally.

Tour operators based in Ulaanbaatar market Bayan Ulgii to particular segments of the tourism market. These include, but are not limited to adventure tourists and cultural tourists. While official tourism statistics for Bayan Ulgii are limited, national-scale tourism statistics are more readily available. Mongolia's top tourist sources are largely from within the broader geographic region and include Russia, China, Korea, Japan, Kazakhstan, followed by the United States, Germany and France ([16], p.161). Nault and Stapleton ([13], p.698) note that in 2008, there were slightly less than 1,500 tourists to Bayan Ulgii with American and Japanese tourists comprising the two largest foreign groups represented. The vast majority of tourists arrive first in Ulaanbaatar by air, although it is possible to arrive via train from China or Russia and to arrive by plane to Bayan Ulgii. Tourists heading to Bayan Ulgii, can arrive by air (international airport), by land border crossings from China or Russia, or by vehicle from Ulaanbaatar. Bayan Ulgii has a small international airport with flights to and from Kazakhstan and other points in Mongolia. Although the exact number of tourists are not available, statistics from border crossings can illustrate a few simple trends. For example, inbound passengers at the two borders, Dayan and Tsagaannuur, and at the Bayan Ulgii airport, who are designated as non-resident (and nongovernment or official visitors) comprised $67.9 \%$ (of 47,170) passengers in 2010, 58.2\% (of 44,251) in 2013 and $35.6 \%$ (of 105,336) in 2016[17]. Although these are relatively small numbers of tourists overall, comprising only $0.2 \%$ and $0.4 \%$ of all tourists to Mongolia in 2013 and 2016 respectively, they have a significant impact on the local economy, equaling hotel incomes of nearly $\$ 370,000$ US in 2013 and $\$ 150,000$ in 2016 [18].

Tourism opportunities in Bayan Ulgii include both small group and individual tours (such as with a guide) and might include a stay at one of the ger (felt dwelling unit) camps, camping, climbing, viewing petroglyphs, and home stays. There are numerous natural attractions in the area, including archeological sites and petroglyphs, Altai Tavan Bogd National Park, the Eagle Hunting Festival and the natural landscape of the region, broadly are attractive for photographers. 
One of the key attractions for outsiders, however, is the existence of the Kazakh population. As an historically isolated population, many Kazakhs of western Mongolia have maintained traditional Kazakh livelihoods and semi-nomadic pastoralism. Thus heritage tourism is one aspect of the broader tourism landscape in this region, although this too is rapidly changing.

\section{DATA \& METHODS}

This paper draws on data and observations from five summer fieldwork seasons in Mongolia, spanning the years 2006-2016, although the data specifically utilized comes from data collected in 2015-2016. Early fieldwork in 2006-2009 was part of a collaborative project focused on the transnational migration of Mongolian Kazakhs (see [3] for more specific information). In 2015, a second collaborative project was initiated. These data include 100 surveys of recent Kazakh migrants to Ulaanbaatar and 36 life history interviews, as well as participant observations and copious field notes. The 2015-2016 data focus on the migration decisions and outcomes of Kazakhs who predominantly migrated from the western regions of Mongolia to Ulaanbaatar and their lives in Ulaanbaatar following migration. Results presented in this article rely primarily on themes emerging from the life history interviews.

Specifically, this paper utilizes two methods for assessing tourism narratives in western Mongolia. Analysis of external narratives is based on evaluation of available official statistics and webbased portrayals of western Mongolia. Much has been written about the Kazakhs and Bayan Ulgii (see for example $[5,9,3,4]$ ), including references to the emerging importance of tourism for household economies. The existence of insider narratives emerged from responses to questions about interviewee visits to and perceptions of western Mongolia, broadly and Bayan Ulgii specifically during the 2015-2016 study. While numerous themes have emerged from these data, this article will explore the concept of heritage tourism as it applies to narratives of place and identity amongst Kazakh migrants to Ulaanbaatar. Specifically I draw on the life history interviews to illustrate how place and identity are intertwined and argue that heritage tourism in BayanUlgii has evolved to serve two audiences and that for these two audiences there are two distinct narratives of culture and consumption. This dual narrative is constructed and consumed by outsider tourists on the one hand and, on the other hand, is consumed by insider co-ethnics, largely comprised of members of the Kazakh diaspora now living away from the home region.

\section{TWO NARRATIVES OF TOURISM IN WESTERN MONGOLIA}

\subsection{Heritage Tourism And Cultural Narratives For Outsiders}

Heritage tourism has two distinct narratives for insiders and outsiders. For tourists, those who are outsiders to the Kazakh ethnic community, there exists a narrative of cultural, and sometimes natural, heritage tourism. There is a preservation and an authenticity aspect to this dimension of the tourist experience. Tour companies promote opportunities to live with nomads and experience rural life in Mongolia. For this group there are numerous attractions in western Mongolia and the narrative here varies between cultural heritage in terms of observing and participating in nomadic herding lifeways and alternatively adventure tourism. For the non-Kazakh tourist, tourism opportunities include heritage tourism and adventure tourism. Tourists might stay in a ger camp to experience life in a traditional felt tent; they might stay in a hotel. Or they might participate in a home stay and live with a local semi-nomadic herding family where they would have the opportunity to observe rural life, ride a horse, maybe make cheese or airag, and generally experience everyday life with a local family.

For the adventure tourist, tents or ger camps are the likely abode and these groups are more likely to be in the area for wildlife viewing, climbing, or viewing the petroglyphs. Bayan Ulgii boasts stunning landscapes, a national park, petroglyphs, and camping. Lastly, there are many researchers in the region who form a semi-touristic category of visitors. There are numerous archeological sites with teams of researchers and students from a wide range of countries, as well as more independent researchers working on issues related to culture, migration, religion, health, ethnomusicology, animal husbandry and ecology.

While this outsider tourist narrative is diverse, it centers on people and environments in a particular state of development. In addition to money spent on travel and lodging while in Bayan Ulgii, a second important distinction between the insider and outsider group of tourists is the 
commodification of culture as evidenced in the consumption of material goods. For outsider tourists finding lodging in a ger camp, consuming herding livelihoods through homestays, and the local production of textiles specifically produced by Kazakh women for tourist consumption are all material manifestations of tourism in the area. Cooperatives such as Altai Craft (formerly located in Bayan Ulgii) and shops such as Mary and Martha, located in Ulaanbaatar (http://www.mmmongolia.com/), underscore the increasing organization of textile production for outsider consumption. Lastly, the recent release of the motion picture film The Eagle Huntress [21] exemplifies the exoticism and appeal to both adventure and cultural tourists. The Eagle Huntress [21] is a story of a young Kazakh girl from Bayan Ulgii and her adoption of the family tradition of eagle hunting, an activity typically practiced by boys and men. The Eagle Huntress [21] has brought the story of western Mongolia to the attention of westerners who might never have considered this remote region as a tourist destination.

Cultural or heritage tourism for outsiders thus has a specific purpose which resonates with the broader literature about household economy diversification and development opportunities as well as critiques about the selective portrayal of a place and the peoples who reside in that place. For example, Barcus and Werner [4] found that more than $50 \%$ of households noted tourism activities of some sort as part of their household income. These activities may include driving tourists, producing food, hosting home-stays, or working in a tourism-based business, such as a restaurant or hotel. Tourism in Bayan Ulgii, while not highly centralized, provides varied levels of opportunity for local residents to diversify household incomes and ultimately generates local-scale development. For outsiders visiting Bayan Ulgii, however, the image of "Kazakh" is one decided upon and promoted by selective tour operators in Ulaanbaatar and Bayan Ulgii, thereby highlighting particular elements of material cultural and livelihood strategy.

\subsection{Heritage Tourism and Cultural Narratives for Insiders}

The second cultural heritage tourism narrative that emerged from the interviews in Ulaanbaatar focuses on co-ethnics who return or visit Bayan
Ulgii to consume their own ethnic Kazakh culture. These are individuals who are not only visiting kin but actively seeking to reinscribe historic cultural narratives and lifeways into their own lives and that of their children. For this population there is a sense of nostalgia and cultural preservation, but the cultural elements desired for preservation and motivations for visiting western Mongolia are quite different than those of the outsider tourist.

Throughout our interviews, one of the emerging themes related to visiting or returning to western Mongolia was the importance of a shared history and specific markers of Kazakh culture. These markers include the importance of language and religion, food and lifeways. Bayan Ulgii Aimag is home to numerous locally-based mosques and the call to prayer can be heard across local communities. The primary language spoken is Kazakh, although the language of inter-ethnic communication is Mongolian. Maintenance and preservation of language emerged as an important concern for many of our interviewees. Some felt torn between speaking Kazakh at home, in order to encourage their children to maintain their ethnic language, and speaking Mongolian at home, in order to be sure their children were fluent in the language of the country. One respondent highlighted the concern: "Some Kazakh people in Ulaanbaatar don't speak their native language. We tell our children that they must speak Kazakh when they are at home. Don't forget your mother language. We always give them suggestions. And also we tell them not to marry Mongolians.... This is how to keep Kazakh culture" (802-0038). This respondent's concern with marriage and linguistic ability highlight the ways in which many other respondents felt their culture might be threatened - through loss of language by younger generations, and by intermarriage amongst Kazakhs and non-Kazakhs.

Many respondents saw visits to western Mongolia as an essential element in maintaining language skills and in enhancing the Kazakh language skills of their children. On these extended visits to the countryside children would be expected to communicate in Kazakh. Likewise, these visits provided opportunities for children to learn about rural lifeways, from horse riding, to sheep and goat milking and herding, to traditional food preparation, and daily life living in a ger. Indeed, many of the interviewees reflected 
extensively on the importance of such experiences in their own childhoods, romanticizing the experiences for us, the interviewers, as well as for themselves. A long retired elder of the community explained to us about his own childhood: "When I was a child I helped my parents, if my father wanted to go somewhere else I often got up early in the morning and I prepared everything and a horse. And I herded animals. When my mother milked the cow I helped her. In the afternoon I also milked sheep with my mother. My childhood passed quite simply, like a herder's simple life." (802-0034). Such memories create a narrative of family unity and the importance of preserving particular lifeways, while simultaneously glossing over the challenges and hardships of nomadic living.

For Kazakhs in western Mongolia as well as those who migrated to Ulaanbaatar, The Eagle Huntress [21] film served as a point of pride amongst our interviewees. Many identified eagle hunting as an important, almost iconic, activity of ethnic Kazakhs. The film thus reinforced these ideas of ethnic unity and pride. The film has only just been released but many in Ulaanbaatar were aware of its existence and spoke with pride about their home place in Mongolia and their own culture.

Our research amongst urban Kazakhs in Ulaanbataar revealed a second narrative of tourism consumption. For ethnic Kazakhs, who were now largely urban dwellers, who had migrated to Ulaanbaatar in the recent past, western Mongolia was held as a place of cultural preservation and exploration, no matter how romantic or nostalgic these imaginaries might be. For these respondents, returning to Bayan Ulgii was an opportunity to participate in lifeways, such as summer herding practices, which reaffirmed their connection to Kazakh culture. Respondents highlighted the importance of being able to speak Kazakh regularly, participate in daily household activities, and perform cultural or religious acts within a community of other Kazakhs. In Ulaanbaatar, in contrast, ethnic Kazakhs are dispersed across the sprawling urban area and most communication is in Mongolian, rather than Kazakh language. Through visits to kin in western Mongolia, ethnic Kazakhs were able to experience immersion in Kazakh culture and reinscribe for themselves and their children a sense of place and identity tied specifically to their own history and culture. In this instance, various aspects of Kazakh culture, such as language and lifeways, becomes commodified. They are the goods and products that ethnic Kazakhs travel to Bayan Ulgii to consume.

For outsider tourists, western Mongolia holds the opportunity to consume a commodified version of "authentic" culture. Indeed, ethnic Kazakhs from Ulaanbaatar are quick to confirm the authenticity of local expressions of Kazakh culture. Tourism narratives thus attract two audiences, insider ethnic Kazakhs and outsider tourists. Three examples of these dual narratives include the preservation of foodways and language and its inherent association with Kazakh identity. For outsiders, this becomes an "authentic" heritage tourist experience, while for ethnic Kazakhs it is viewed through the lens of cultural preservation. Eagle hunting is also exemplified although for outsiders it too is a way to engage with authenticity while for ethnic Kazakhs it represents a confirmation of identity and unity in being Kazakh. Lastly, while textiles are traditionally produced by Kazakh women in the home, the move to cooperatives and production of textiles for tourists changes the dynamic of this particular consumable good. While these textiles are a physical representation of local culture, few respondents identified textiles as an important element of cultural preservation, thus the importance of these artifacts may rest largely with an external audience of consumers.

In summary, tourism in western Mongolia has two distinct audiences who consume different cultural narratives. Outsider tourists seek to consume an "authentic" culture through home visits, immersion in the expansive landscape, and through activities such as eagle hunting and herding and through material products such as traditional textiles. Their presence in Bayan Ulgii adds diversity to local household economies [4] as well as supporting an increasing number of small hotels, restaurants and transportation services. For ethnic Kazakhs, visits to kin takes on a touristic aspect as well. For this group, there is a renewed sense of identity and pride in being ethnic Kazakh. Greater acknowledgement by outsiders, including tourists, underscores the sense of selfidentity and of identity beyond Mongolian national identities. Some traditions are also conservedto a greater extent than might otherwise 
be the case. Language, for example, as well as textiles. This creates space and enough perceived economic value to preserve other tangible forms of "culture". The narrative of Kazakhness and the perceived importance of maintaining ethnic Kazakh culture seems to be gaining support. The community of Kazakhs in Ulaanbaatar are keen to see this continue. While often perceived as rural and poor amongst ethnic Mongols, appreciation from external audiences bolsters local pride and affirms a positive narrative of cultural identity.

\section{CONCLUSIONS}

In this article the question is posed as to what role tourism plays in sustaining cultural narratives for ethnic minority populations in Mongolia. Utilizing data from interviews conducted with recent migrants to Ulaanbaatar, I argue that cultural heritage tourism in Bayan Ulgii Mongolia has evolved to serve two audiences, an insider, co-ethnic consumer and an outsider tourist consumer. For each of these two audiences there is a distinct narrative of culture and consumption. While each audience utilizes similar tourist-based activities or material goods and experiences, the value attributed to these good and activities varies between insiders and outsiders. This article focuses specifically on the emerging value of heritage tourism for co-ethnics who have migrated away from the home region and suggests the emergence of a more diaspora-based tourism.

Further, beyond just household economic diversification, diaspora tourism has a strong influence on contemporary identity and narratives of "nation" and "community", particularly for members of the community who live far away. The perception amoungst interviewees is that coethnics residing in Bayan Ulgii will preserve traditions and lifeways while those, including themselves, with more urban and global lifestyles, will struggle to keep traditions [2]. Thus the remote rural province of Bayan Ulgii is seen as a place of cultural heritage preservation for Kazakhs while at the same time, it is seen as an "authentic" expression of local culture by outsider tourists.

Although this article has identified two narratives of culture and consumption, one for insiders and one for outsiders, it is important to note that these narratives mutually reinforce positive images of Kazakh identity and heritage. For example, the visual and material goods (such as films, tourist brochures, advertisements) produced to promote Bayan Ulgii to outsiders or external audiences, also generate pride in Kazakh identity and heritage for Kazakh residents of both Bayan Ulgii and Ulaanbaatar. Whether these synergies are intentional outcomes of local insider tourism development strategies or are simply cooccurring with rising interest amongst Kazakhs in cultural preservation will require further, more intentional research into the growing tourism industry in western Mongolia.

Heritage or cultural tourism in Bayan Ulgii is thus facilitating the production of a narrative that Kazakhs who have moved away from the area are seeking to re-inscribe or infuse into their now urban or global lifestyles. At this stage of tourism development, the outcomes are favorable for both the community and the individuals. However, to the extent that international attention, such as through the promotion of the film The Eagle Huntress [21], begins to attract more formal tourism enterprises or mass tourism, these advantages are likely to deteriorate.

\section{REFERENCES}

[1]. Ancien, D., M. Boyle and R. Kitchin. 2009. The Scottish diaspora and diaspora strategy: Insights and lessons from Ireland. Scottish Government Social Research available: $\quad$ www.scotland.gov.uk/socialresearch. Accessed 14 July 2017.

[2]. Barcus, H. R. and A. Shugatai. Immobile populations as anchors of rural ethnic identity: Narratives of place and migration in the Global SouthIn Review.

[3]. Barcus, H. R. and C. Werner. 2010. The Kazakhs of western Mongolia: Transnational migration from 19902008. Asian Ethnicity 11(2): 209-228.

[4]. Barcus, H. R. and C. Werner. 2016. Choosing to Stay: (Im)Mobility Decisions Amongst Mongolia's Ethnic Kazakhs. Globalizations 14(2):32-50.

[5]. Diener, A. C. 2009. One homeland or two: The nationaliztion and trans nationalization of Mongolia's Kazakhs. Stanford University Press: Chicago, Illinois.

[6]. Franquesa, J. B. and M. Morell. 2007. Transversal indicators and qualitative observatories of heritage tourism. In Cultural Tourism: Global and Local Perspectives Ed Greg Richards. New York: The Haworth Hospitality Press, Inc. 169-194.

[7]. Huang, W.-J., W. J. Haller, and G. P. Ramshaw. 2013. Diaspora tourism and homeland attachment: An exploratory analysis. Tourism Analysis 18:285-296.

[8]. Johnston, A. 2006. Is the Sacred for Sale? Tourism and Indigenous Peoples. London: Earthscan.

[9]. Keitumetse, S., L. McAtackney and G. Senata (2011). Memory and identity as elements of heritage tourism in Southern Africa. Eds. H. Anheier and Y. R. Isar. In Heritage, Memory and Identity Sage: London, 157-168. 
[10]. Kelner, S. 2010. Tours that Bind: Diaspora, Pilgrimage and Israeli Birthright Tourism. New York, NY: New York University Press.

[11]. McIntosh, A. J., T. Hinch and T. Ingram. 2002. Cultural identity and tourism. International Journal of Arts Management 4(2): 39-49.

[12]. McKercher, B. and H. du Cros. 2002. Cultural Tourism The Partnership between Tourism and Cultural Heritage Management. New York: The Haworth Hospitality Press.

[13]. Nault, S. and P. Stapleton. 2011. The community participation process in ecotourism development: a case study of the community of Sogoog, Bayan-Ugii, Mongolia. Journal of Sustainable Tourism 19(6):695712

[14]. Newland, K. and C. Taylor. 2010. Heritage Tourism and Nostalgia Trade: A Diaspora Niche in the Development Landscape. Washington, DC: Migration Policy Institute.

[15]. NSOM (National Statistical Office of Mongolia). 2013. Mongolian Statistical Yearbook 2013. NSOM Ulaanbaatar, Mongolia.

[16]. NSOM (National Statistical Office of Mongolia). 2017a NUMBER OF INBOUND PASSENGERS, by immigration post and purpose of visit, quarter, available at http://www.1212.mn. Ulaanbaatar, Mongolia.

[17]. NSOM (National Statistical Office of Mongolia). 2017b. INCOME OF HOTELS, by quarterly, by aimag and by cumulative total, available at http://www.1212.mn. Ulaanbaatar, Mongolia.

[18]. NSOM (National Statistical Office of Mongolia). 2011 Mongolia National Census 2010 Provision Results. (2011). National Statistical Office of Mongolia Archived September 15, 2011 (in Mongolian.)

[19]. Portisch, A. 2009. Techniques as a window onto learning: Kazakh women's domestic textile production in westernMongolia. Journal of Material Culture 14(4): 471-493.

[20]. Richards, G. 2007. Introduction: Global trends in cultural tourism. In Cultural Tourism: Global and Local Perspectives Ed G. Richards. New York: The Haworth Hospitality Press, Inc. 1-24.
[21]. Ridley, D., O. Bell, S. Chang. S. Reiss (Producers). 2016. The Eagle Huntress (Motion Picture). U.K., U.S., Mongolia: Sony Pictures Classics.

[22]. Saarinen, J., F. Becker, H. Manwa, D. Wilson (Eds.), 2009. Sustainable Tourism in Southern Africa: Local Communities and Natural Resources in Transition. Channel View, Bristol.

[23]. Saarinen, J., M. Lenao. 2014. Integrating tourism to rural development and planning in the developing world. Development Southern Africa 31(3): 363-372.

[24]. Spenceley, A. and D. Meyer. 2012. Tourism and poverty reduction: theory and practice in less economically developed countries. Journal of Sustainable Tourism. 20(3): 297-317.

[25]. Worden, N. 2010. National identity and heritage tourism in Melaka. In Heritage Tourism in Southeast Asia. Eds. M. Hitchcock, V. T. King and M. Parn well. Honolulu, HA: University of Hawaii Press.

Holly Barcus is a geographer who has been teaching at Macalester since 2005. Her interests reside at the intersection of migration, ethnicity and rural peripheries. For the past twelve years she has been working in western Mongolia amongst the Kazakh population considering questions of identity, environment, and changing migration trajectories. She holds degrees from the University of North Carolina at Charlotte, Kansas State University and The Australian National University. She holds positions on editorial board for the Journal of Rural Studies and as a co-chair of the International Geographical Union's Commission on the Sustainability of Rural Systems (IGU-CSRS). 


\title{
Tính lưu thông và sự bền bỉ của các câu chuyện văn hóa: Du lịch di sản và câu chuyện văn hóa của người bản địa và du khách tại phương Tây Mongolia
}

\author{
Holly Barcus \\ Khoa Địa lý, Đại học Macalester, Saint Paul Minnesota \\ Email tác giả liên hệ: barcus@macalester.edu
}

Ngày nhận bản thảo: 10-11-2017; Ngày chấp nhận đăng: 03-12-2017; Ngày đăng: 30-6-2018

Tóm tắt-Nằm trong khuôn khổ các cuộc tranh luận hiện nay về tác động của du lịch di sản văn hóa đối với cộng đồng dân tộc thiểu số vùng nông thôn, bài viết này nghiên cứu trường hợp du lịch di sản văn hóa ở Bayan Ulgii Mông Cổ, đặt những tranh luận về địa điểm và bản sắc tộc người có liên quan đến ngành du lịch này bên cạnh những tranh luận về giá trị kinh tế của nó. Kết quả so bộ cho thấy rằng, việc người Kazakhs ngày càng được quan tâm như một nhóm sắc tộc văn hóa thiểu số ở Mông Cổ và những tự sự về sức sống bền bỉ của họ đã được quốc tế thừa nhận ngày càng nhiều, từ đó thúc đẩy sự phát triển mạnh mẽ hơn của du lịch đến các vùng dân cư này. Tuy nhiên, một trong những sản phẩm đầu ra chính yếu của việc khai thác cảnh quan di sản này chính là sự tiêu thụ các câu chuyện về bản sắc văn hóa của những người Kazakh di cư, những người luôn khao khát tái tạo một thứ "bản sắc văn hóa truyền thống" cho con cái của họ. Do đó, điều này tạo điều kiện cho việc kiến tạo một cảm thức chung về bản sắc trong một cộng đồng đang bị phân tán nhanh chóng. Tuy nhiên, nó cũng thách thức ý niệm xem sản xuất và tiêu dùng như là cạnh tranh nhau thay vì bổ trợ nhau tại các địa điểm du lịch nông thôn mới nổi của những quốc gia đang phát triển.

Tù̀ khóa-du lịch văn hóa, Ulgii, Olgii, căn cước, tụ̣ sụ̣, di dân 